
\title{
25 Research Soure \\ Effect of Rainfall and pH on Musty Odor Produced in the Sanbe Reservoir
}

\section{Sangyeob Kim ( $\nabla$ kim@soc.shimane-u.ac.jp )}

Shimane University

\section{Shohei Hayashi}

Shimane University

\section{Shingo Masuki}

Shimane University

\section{Kazuhiro Ayukawa}

Shimane University

\section{Shuji Ohtani}

Shimane University

\section{Yasushi Seike}

Shimane University

\section{Research Article}

Keywords: Harmful cyanobacterial blooms (HCBs), water systems, lakes , reservoirs , 2-methylisoborneol (2-MIB)

Posted Date: February 17th, 2021

DOl: https://doi.org/10.21203/rs.3.rs-203635/v1

License: (c) (1) This work is licensed under a Creative Commons Attribution 4.0 International License. Read Full License

Version of Record: A version of this preprint was published at Water on December 15th, 2021. See the published version at https://doi.org/10.3390/w13243600. 


\title{
Effect of Rainfall and pH on Musty Odor Produced in the Sanbe Reservoir
}

\author{
Sangyeob Kim ${ }^{1, *}$, Shohei Hayashi ${ }^{2}$, Shingo Masuki ${ }^{1}$, Kazuhiro Ayukawa ${ }^{1}$, Shuji \\ Ohtani $^{3}$, and Yasushi Seike ${ }^{1, t}$ \\ ${ }^{1}$ Estuary Research Center, Shimane University, 1060 Nishikawatsu-cho, Matsue-shi, Shimane, 690-8504, \\ Japan
}

${ }^{2}$ Faculty of Life and Environmental Science Shimane University, 1060 Nishikawatsu-cho, Matsue, Shimane, 690-8504, Japan

${ }^{3}$ Faculty of Education, Shimane University, 1060 Nishikawatsu, Matsue, Shimane, 690-8504, Japan

"kim@soc.shimane-u.ac.jp

these authors contributed equally to this work

\begin{abstract}
Harmful cyanobacterial blooms (HCBs) are continuously formed in water systems such as reservoirs and lakes around the world. In particular, geosmin and 2-methylisoborneol (2-MIB), which are made by cyanobacteria, have caused serious musty-odor problems in the drinking water of the Sanbe reservoir in Japan. To investigate the cause of this musty odor, we conducted field observations for five years (20152019). As a result, it was determined that the geosmin was caused by the cyanobacteria as

Dolichospermum crassum and Dolichospermum planctonicum, and 2-MIB was caused by the cyanobacteria as Pseudanabaena sp and Aphanizomenon cf. flos-aquae. It was also determined that the occurrence of geosmin and 2-MIB are influenced by changes in water temperature and $\mathrm{pH}$ due to the inflow of rainfall. Especially, the geosmin and 2-MIB tended to occur in low rainfall conditions. When there is low rainfall, the reservoir changes to an alkaline state due to the consumption of $\mathrm{CO}_{2}$ by the photosynthesis of phytoplankton. In an alkaline reservoir, $\mathrm{CO}_{2}$ exists in the form of bicarbonate $\left(\mathrm{HCO}_{3}^{-}\right)$; thus, under these condition cyanobacteria will increase because it uses both $\mathrm{CO}_{2}$ and bicarbonate $\left(\mathrm{HCO}_{3}{ }^{-}\right)$ for photosynthesis. Our study suggests that for solving the musty-odor problem in the reservoir, it is important to control the reservoir's $\mathrm{pH}$. Moreover, more focus should be place in managing the water quality problem of the Sanbe Reservoir, especially, during low rainfall years. The results of this study will help in addressing odor related water quality problem in other reservoirs.
\end{abstract}

\section{Introduction}

Serious damage to water resources, marine products, living environment, and tourism resources can occur due to harmful cyanobacterial blooms (HCBs) in reservoirs around the world ${ }^{1-7}$. When HCBs appear in a reservoir, appearance and musty-odor problems can make humans uncomfortable. In particular, the musty-odor (earth odor, ink odor) that is continuously generated in water systems such as reservoirs and lakes around the world has become an extremely serious problem in drinking water source ponds ${ }^{8-12}$. If a large amount of the musty odor is created, it requires activated carbon treatment, which causes economic loss. In fresh-water systems, there are many cases in which the musty odor is made from Geosmin and 2-methylisoborneol (2-MIB). Geosmin was reported in 1964 and 2-MIB was reported in 
$1969^{13-14}$. In Japan, the continuous generation of musty-odor has become a problem in Lake Shinji, which is a brackish water area, and in Sanbe Reservoir, in Shimane Prefecture. When a high concentration of geosmin occurred at Lake Shinji in 2007, producers and wholesalers who harvest brackish-freshwater clams have difficulty responding due to the moldy-odor smell on the clams. It was verified that the moldy odor was formed by the cyanobacteria Coelosphaerium sp. ${ }^{15-16}$. However, the cause of the occurrence of the cyanobacteria was unknown. At Sanbe Reservoir, located in the mountainous area of Oda City, Shimane Prefecture (Fig.1), a musty-odor due to geosmin and 2-MIB has been produced in recent years. In that reservoir, when a musty-odor of $10 \mathrm{ng} / \mathrm{L}$ or more, which is the Japanese water quality standard (Drinking Water Quality Standards in Japan, Ordinance of Ministry of Health, Labor and Welfare No. 101,2003 ) occurs, it is removed using activated carbon or ozone because it is partly used as a water supply ${ }^{17-18}$. An additional cost of about 10 million yen every year is required to remove the musty odor. Therefore, it is important to investigate the musty odor occurrence mechanism; however, this has not yet been clarified. This is because the ecological characteristics that differ from species of cyanobacteria, their interrelationships with the surrounding biota, their physical and chemical actions, and the environment, are intricately linked ${ }^{9}$. Although the species that generate musty odors have been investigated by genetic analysis ${ }^{4}$, the relationship between the occurrence of these species and environmental factors around the water area has not been clarified. To clarify the relationship between environmental factors such as water quality, weather conditions, and musty odor, it is necessary to accumulate sufficient data, but such research has not yet been conducted. In this paper, we will discuss the relationship between environmental changes around the reservoir and the generation of musty-odor using data collected from a musty-odor survey conducted at the Sanbe Reservoir for the past five years by our research group.

\section{Methods}

\section{Sampling Geosmin and 2-methylisoborneol (2-MIB)}

Sampling water was collected from October 2017 to December 2019 at St.1 of the Sanbe Reservoir in

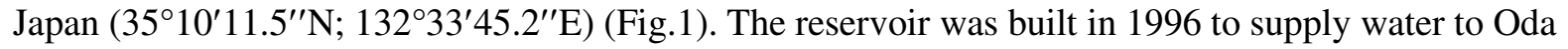
City, flood control for the Sanbe River, drinking water, agricultural irrigation, and power generation. The main inflow comes from the east and there are residential areas in the watershed. In the water purification plant located in the south of the reservoir, drinking water was constantly taken from a $10 \mathrm{~m}$ depth (EL 117 $\mathrm{m}$ ) and delivered to the purification plant through a tunnel. Water was sampled from water surfaces at depths of $0.5,9,17$, and $27 \mathrm{~m}$ at St.1 (Fig.1) using a water sampler (Kitahara 2-L type Rigo Co., Ltd.,). Geosmin and 2-MIB concentrations in the water were measured using a gas chromatograph (GC-7890, Agilent, USA) equipped with a quadrupole mass spectrometer (MS) (5977B, Agilent) and a purge and trap autosampler (Aotmx, Teledyne Tekmar, USA) as described by Godo et al. (2017) ${ }^{15}$ and the Ordinance of the Ministry of Health, Labour and Welfare No. 261, 2003. Gas chromatography/mass spectrometry (GC/MS) analysis was carried out in selected ion monitoring mode $(\mathrm{m} / \mathrm{z}, 112)$. As an internal standard, 2,4,6-Trichloroanisole-d3 $(\mathrm{m} / \mathrm{z}, 115)$ was spiked into a sample. The detection limit was $1 \mathrm{ng} / \mathrm{L}$. We used the geosmin, 2-MIB, inflow freshwater, water temperature, etc. data from the purification plant, taken from regular inspections by the Shimane Prefecture.

\section{Vertical distribution of water quality}

Continuous observation was carried out from April 2018 to March 2019 using an automatic elevating water quality meter ( $\mu$ plofiler, Hydrolab, model DS5X) installed near St.1 (Fig.1). Vertical measurements of water temperature, electrical conductivity (EC), turbidity (Turb.), Phytoplankton (Chl$a), \mathrm{pH}$, water temperature, and cyanobacteria index (PCY) from the lake surface to the lake bottom were measured every hour. 


\section{Identification of phytoplankton}

Water for observation of phytoplankton was sampled from water surfaces at depths of 0.5 or $1.0 \mathrm{~m}$ at St.1 (Fig.1) using a water sampler (Kitahara 2-L type Rigo Co., Ltd.,) in June and September in 2017 and 2019 when odor has massively occurred. After that, the sampled was brought back to the laboratory, 200 $\mathrm{mL}$ of water was filtered with a pore size of $0.45 \mu \mathrm{m}$ membrane filter. And a 100-fold concentrated samples were prepared which are made by the filtered sample was scraped off with a microspartel spatula to adjust $2 \mathrm{~mL}$. A sample of 2017 was observed by performing the following double fixing method. 1) Add $2 \mathrm{~mL}$ of glutaraldehyde to a 100-fold concentrated raw $2 \mathrm{~mL}$ sample to make $4 \mathrm{~mL}$, and leave it for a while to fix. 2) Remove the supernatant liquid with a pipette as much as possible, and making the precipitate sample containing plankton to about $0.2 \mathrm{~mL}$, then add $1.8 \mathrm{~mL}$ of formalin to make $2 \mathrm{~mL}$ sample. The microscopic observation is carried out using an Olympus BX60 objective lens 100x. And the relative frequency was divided into 5 stages: high abundant(cc), abundant (c), common (+), rare (r), very rare (rr), and high abundant or abundant was the dominant species.

\section{Results}

Figure 2 shows the concentration of geosmin and 2-MIB at a the epilimnion (0.5-m depth from the water surface) at St.1. Geosmin was detected in values exceeding $100 \mathrm{ng} / \mathrm{L}$ in June 2016, June 2017, June 2019, and July 2019, and a high concentration of odor tends to occur in early summer (June to July). On the other hand, 2-MIB was detected in values exceeding $100 \mathrm{ng} / \mathrm{L}$ in November 2015, August and September 2017, and November 2019, a high concentration of musty-odor tends to occur from summer to late autumn (August to November). However, in 2018, both geosmin and 2-MIB showed a low concentration below $10 \mathrm{ng} / \mathrm{L}$ (the Japanese water quality standard water quality).

Table 1 indicate that the identification of phytoplankton results in 2017 and 2019. At that time, there were cyanobacteria, diatoms, dinoflagellates, euglenoids, and green algae appeared, but only cyanobacteria that may produce musty odors are shown. When geosmin has occurred in June 2017, although the dominant species do not exist, cf. Cuspidothrix sp. was + , and Dolichospermum crassum was r. whereas when 2-MIB has occurred in September 2017, the dominant species was cf. Geitlerinema sp. . Also, it indicated that Aphanothece sp. and Pseudanabaena sp. were r. On the other hand, In June 2019 when geosmin has occurred, Dolichospermum planctonicum was c, Dolichospermum crassum was + . whereas when 2-MIB has occurred in September 2019, cf. Geitlerinema sp. and Aphanizomenon cf. flosaquae were c, Pseudanabaena sp. was +, Aphanocapsa sp. and Microcystis sp. were r. Using the single algae culture strains of these species, the presence or absence of the ability to generate musty odor was determined by measuring the generated geosmin and 2-MIB and genetic analysis of the single algae. As a result, Dolichospermum planctonicum and Dolichospermum crassum were geosmin-producing species, while Pseudanabaena sp. and Aphanizomenon cf flos-aquae were 2-MIB-producing species. The production of geosmin and 2-MIB by these species has also been reported by Watson et al. (2016) ${ }^{13}$. However, the cyanobacteria cf.Geitlerinema sp. and cf. Cuspidothrix sp., which were sometimes dominant in Sanbe Reservoir, did not have the ability to produce musty odor. Therefore, to reduce the damage caused by the musty odor of the surface water of Sanbe Reservoir, it is necessary to pay particular attention to the growth behavior of D. planctonicum, D. crassum, P. sp. and A. cf. flos-aquae.

Figures 3 and 4 show the time-series changes of geosmin and 2-MIB at depths of $0.5 \mathrm{~m}$ below the surface of the water, $9 \mathrm{~m}$ (EL $118 \mathrm{~m}$ ), $17 \mathrm{~m}$ (EL $110 \mathrm{~m}$ ), and $27 \mathrm{~m}$ (EL $1 \mathrm{~m}$ above the bottom). Geosmin was measured not only on the epilimnion (at $0.5 \mathrm{~m}$ ) but also at concentrations above $10 \mathrm{ng} / \mathrm{L}$ at the 
hypolimnion (1 $\mathrm{m}$ above the bottom) in the Sanbe reservoir (Fig.3). In contrast, 2-MIB tended to increase in the hypolimnion with a slight delay, especially when increasing on the epilimnion (Fig.4).

Figures 5 and 6 show the vertical distribution of 2016 (geosmin) and 2017 (2-MIB) when detected at a high concentration (over $100 \mathrm{ng} / \mathrm{L}$ ). It was confirmed that the geosmin and 2-MIB concentrations decreased from the upper layer to the lower layer. However, as shown by the geosmin on July 11, 2016, and 2-MIB on September 15, 2017, and November 12, 2017, their concentration was confirmed near the bottom layer, although it was relatively low.

Table 2 shows the monthly average of freshwater inflows for each year from 2016 to 2019. Here, the underscore indicates that a month larger than the average of each month occurred during the past four years. In 2018, when the concentrations of both geosmin and 2-MIB were low, it was confirmed that the annual inflow was the highest during the four years $\left(1.64 \mathrm{~m}^{3} / \mathrm{s}\right)$. Furthermore, during the past four years, it was confirmed that the highest inflow $\left(2.67 \mathrm{~m}^{3} / \mathrm{s}\right)$ in 2018 occurred from May to July and September. In addition, there was a huge inflow $\left(2.14 \mathrm{~m}^{3} / \mathrm{s}\right)$ in September 2016.

Figure 7 shows a comparison of the amount of inflow with Geosmin on the epilimnion from 2016 to 2018. In 2018, there were about three peaks of inflow over $3 \mathrm{~m}^{3} / \mathrm{s}$, compared to the inflow in May 2016 and 2017 when high concentrations of Geosmin were confirmed.

Figure 8 shows a comparison of surface 2-MIB on the epilimnion and the amount of inflow from 2017 to 2019 . There were four peaks of inflows over $7 \mathrm{~m}^{3} / \mathrm{s}$ from July to October in 2018, compared to the inflows of 2017 and 2019.

Figure 9 shows the relationship between geosmin, 2-MIB, and water temperature on the epilimnion in Sanbe Reservoir from October 2015 to December 2019. The occurrence of high concentration (100 ng/L or higher) geosmin was observed in a relatively narrow water temperature range of 20 to $25^{\circ} \mathrm{C}$. On the other hand, the occurrence of high-concentration 2-MIB was observed in a wider water temperature range of 13 to $28^{\circ} \mathrm{C}$.

Figure 10 shows the time-series changes at a depth of $1 \mathrm{~m}$ ( $\mu$ profiler data) at the Sanbe reservoir station and the inflow water temperature, rainfall from May to October 2017, 2018, and $2019^{19}$. The fluctuation patterns of water temperature on the epilimnion and the inflow water temperature are very similar. Furthermore, there is a high correlation between the water temperature on the epilimnion and the inflow water temperature for all periods $\left(\mathrm{p}<0.000, \mathrm{R}^{2}=0.989\right)$. The significant decrease in water temperature from June to July in 2018 was confirmed to be due to the rapid increase in total rainfall (268 $\mathrm{mm}$ ) inflow over the 9 days from 28 June to 6 July.

Figure 11 shows the vertical distribution of the electrical conductivity (EC) and turbidity (Turb.), Phytoplankton content (Chl- $a$ ), $\mathrm{pH}$, water temperature, and cyanobacteria index (PCY) in the Sanbe reservoir from June 21 to July 20, 2018. It can be inferred that the decrease in EC concentration on 30 June and 7 July was due to the invasion of two inflows of freshwater to the epilimnion. This means that the inflow of freshwater was muddy water due to the turbidity on the epilimnion also increased at that time. Furthermore, water temperature, $\mathrm{pH}$, and Chl- $a$ decreased at the same time. After 12 July, Chl- $a$ and $\mathrm{pH}$ increased slowly with the increasing water temperature over $25^{\circ} \mathrm{C}$, whereas PCY was only slightly detected near the water surface. 


\section{Discussion}

\section{Musty-Odor-producing cyanobacteria Species}

During the five-year observation period from 2015 to 2019, the musty odor caused by the geosmin and 2-MIB was noted every year. Geosmin tended to occur at a high concentration of $100 \mathrm{ng} / \mathrm{L}$ or more on the epilimnion from June to July, and in a low concentration of about $10 \mathrm{ng} / \mathrm{L}$ on the hypolimnion for most years (Figs. 3 and 5). In contrast, 2-MIB tended to increase in the hypolimnion after a high concentration on the epilimnion occurred from August to November (Figs. 4 to 6). Especially, as show Table.1, it is speculated that the high concentration of geosmin is caused by the cyanobacteria of Dolichospermum crassum and Dolichospermum planctonicum ${ }^{13}$ from June to July, while the occurrence of high concentrations of 2-MIB is caused by the cyanobacteria of Pseudanabaena sp and Dolichospermum planctonicum ${ }^{13}$ from August to November.

\section{Effect of water temperature and $\mathrm{pH}$ changing due to rainfall on the musty odor producing.}

In 2018, there was no occurrence of high concentrations of both geosmin and 2-MIB. The year 2018 has the highest annual rainfall for five years (Table 2). And the occurrence of geosmin and 2-MIB were not observed after an inflow of over $7 \mathrm{~m}^{3} / \mathrm{s}$ of inflow (Fig.7 and 8). Therefore, it is assumed that the change in musty odor is affected by water quality fluctuations due to inflow. Furthermore, the occurrence of high-concentration geosmin was observed in a relatively narrow water temperature range $\left(20 \sim 25^{\circ} \mathrm{C}\right)$, while the occurrence of high-concentration 2-MIB was observed in a wide water-temperature range (Fig.9). And as shown in Fig.10, the water temperature on the epilimnion at the Sanbe reservoir was greatly affected by the inflow water temperature. In particular, the water temperature in the Sanbe reservoir decreased below $20^{\circ} \mathrm{C}$ with the increasing inflow due to heavy rainfall (Table 2). This is one of the reasons why the geosmin did not occur at high concentrations (see Fig.9).

And the environmental factors required for phytoplankton growth are affected not only by water temperature but also the insolation, sufficient nutrients, and concentration of carbon dioxide $\left(\mathrm{CO}_{2}\right)$ or bicarbonate $\left(\mathrm{HCO}_{3}^{-}\right)$. The inorganic carbon acquisition by marine phytoplankton has been extensively studied in laboratory cultures of green algae ${ }^{20,21}$, cyanobacteria ${ }^{20,22}$, and diatom ${ }^{22}$. These studies have shown that these organisms utilize $\mathrm{HCO}_{3}{ }^{-}$as a photosynthetic $\mathrm{C}$ source. The uptake of $\mathrm{HCO}_{3}{ }^{-}$by cyanobacteria $^{20,22}$ appears to occur through a direct transport system exclusively, while both direct and indirect mechanisms of $\mathrm{HCO}_{3}{ }^{-}$uptake have been documented in green algae ${ }^{21}$ and diatom ${ }^{22}$. In addition, Tortell and Morel (2002) ${ }^{22}$ have reported that phytoplankton assemblages grown under low- $\mathrm{CO}_{2}$ conditions $(150 \mathrm{ppm})$ possessed external CA activity and took up $\mathrm{HCO}_{3}^{-}$following its dehydration to $\mathrm{CO}_{2}$, whereas the assemblages cultured under high- $\mathrm{CO}_{2}(750 \mathrm{ppm})$ appeared to lack external CA activity and rely solely on $\mathrm{CO}_{2}$ as an exogenous source of carbon for photosynthesis.

In seawater ( $\mathrm{pH} 8.3$ ), the vast majority of dissolved inorganic $\mathrm{C}$ (DIC) exists as $\mathrm{HCO}_{3}{ }^{-23}$, with $<1 \%$ of free $\mathrm{CO}_{2}$ as the substrate for $\mathrm{C}$ fixation ${ }^{24}$. Whereas, in freshwater lakes (pH 6-9), generally decreases to pH 6-7 after rainfall, thus free $\mathrm{CO}_{2}$ is about 70-20\% (high- $\mathrm{CO}_{2}$ state). Therefore, according to the results of Tortell and Morel (2002) ${ }^{22}$, it is inferred that the growth of green algae and diatoms at low-pH (i.e., high- $\mathrm{CO}_{2}$ ) is mainly $\mathrm{CO}_{2}$ dependent in Sanbe reservoir. In addition, it has been suggested that the dominance of cyanobacteria in high-pH freshwaters (i.e., low- $\mathrm{CO}_{2}$ ) is attributable to the ability to utilize directly the abundant $\mathrm{HCO}_{3}{ }^{-}$ion as a source of inorganic $\mathrm{C}$ for photosynthesis ${ }^{25}$. Thus, species that possess direct $\mathrm{HCO}_{3}{ }^{-}$transport mechanisms (e.g., cyanobacteria) may gain a competitive advantage than those that rely solely on $\mathrm{CO}_{2}$ uptake or indirect $\mathrm{HCO}_{3}{ }^{-}$uptake via external CA-catalyzed dehydration. As shown in Fig.11, in years when rainfall is higher than normal, the $\mathrm{pH}$ in the reservoir decreases as the inflow water (low $\mathrm{pH}$ ) to the reservoir increases. As a result, diatoms, and green algae other than cyanobacteria were able to grow sufficiently, and the competitive relationship between the three parties was reset, so it was judged that the growth of cyanobacteria was suppressed. On the other hand, the 
occurrence of 2-MIB was also considered to have been controlled by the inflow from August to September 2018 (Table 2 and Fig.8). However, to clarify the more accurate growth mechanism of cyanobacteria, it is also necessary to collect and examine information on growth factors such as $\mathrm{C}$ : N: P ratio ${ }^{26}$.

In managing the odor in the reservoir, it is important to control the reservoir's $\mathrm{pH}$. Moreover, it is more important to pay attention to the years when the rainfall is less than normal. In this study, only the effects of cyanobacterial geosmin and 2-MIB, which occur in a large amount in epilimnion, were considered. It is also necessary to consider the effect of geosmin and 2-MIB formed by actinomycetes in the hypolimnion although it occurs in small amounts. The related analysis is now underway. 


\section{References}

1. O'Neil, J. Davis, T. Burford, M. \& Gobler, C. The rise of harmful cyanobacteria blooms: the potential roles of eutrophication and climate change. Harmful Algae, 14, 313-334 (2012).

2. Bahareh, N \& Samaneh J.P. Toxic compounds produced by cyanobacteria belonging to several species of the order Nostocales: A review,J Appl Toxicol, 1-39 (2020).

3. Soukaina, El.A.Z., Richard, M., El, M.R, Fatima, El.K, Alexandre, C., Vitor, V. \& Brahim, O,. Harmful Cyanobacterial Blooms (HCBs): innovative green bioremediation process based on anti-cyanobacteria bioactive natural products. Archives of Microbiology, https://doi.org/10.1007/s00203-020-02015-6 (2020).

4. Paerl, H.W., Fulton, R.S., Moisander, P.H. \& Dyble, J. Harmful freshwater algal blooms, with an emphasis on cyanobacteria. Sci. World J., 1, 76-113 (2001).

5. Paerl, H.W. \& Otten, T.G. Harmful cyanobacterial blooms: Causes, consequences, and controls. Microb. Ecol., 65, 995-1010 (2013).

6. Chorus, I. \& Bartram, J. Toxic Cyanobacteria in Water: A Guide to Their Public Health Consequences, Monitoring and Management, World Health Organization: London, UK, New York, NY, USA, ISBN 0-419-23930-8 (1999).

7. Chong, S., Lee, H. \& An, K.-G. Predicting Taste and Odor Compounds in a Shallow Reservoir Using a Three-Dimensional Hydrodynamic Ecological Model. Water, 10, 1396 (2018).

8. Pham, T.L., Bui, M.H. \& Driscoll, M. First report of geosmin and 2-methylisoborneol (2-MIB) in Dolichospermum and Oscillatoria from Vietnam. Limnology, Published online (2020).

9. Zaitlin, B \& Watson S.B. Actinomycetes in relation to taste and odour in drinking water: Myths, tenets and truths. Water Res B,40(9),1741-1753 (2006).

10. Jüttner, F. \& Watson, S.B.Biochemical and ecological control of geosmin and 2-methylisoborneol in source waters. Appl. Environ. Microbiol. 73 (14), 4395-4406 (2007).

11. Su M., Gaget, V., Giglio, S., Burch, M., An, W. \& Yang, M. Establishment of quantitative PCR methods for the quantification of geosmin-producing potential and Anabaena sp. in freshwater systems. Water Res, 47(10),3444-3454 (2013).

12. Suurnäkki, S., Gomez-Saez, G.V., Rantala-Ylinen, A., Jokela, J., Fewer, D.P. \& Sivonen, K. Identification of geosmin and 2-methylisoborneol in cyanobacteria and molecular detection methods for the producers of these compounds. Water Res, 68, 56-66 (2015).

13. Watson, S. B, Monis, P, Baker, P \& Giglio, S. Biochemistry and genetics of taste and odor producing cyanobacteria. Harmful Algae, 54, 112-127 (2016).

14. Smith, V.H., Denlinger, J.S., de Noyelles, F., Campbell, S., Pan, S., Randtke, S.J., Blain, G.T. \& Strasser, V.A. Managing taste and odor problems in a eutrophic drinking water reservoir. J. Lake Reserv. Manag., 18, 319-323 (2002).

15. Godo, T., Saki, Y., Nojiri, Y., Tsujitani, M., Sugahara, S., Hayashi, S., Kamiya, H., Ohtani, S. \& Seike, Y. Geosmin-producing species of Coelosphaerium (Synechococcales, cyanobacteria) in lake Shinji, Japan. Sci. Rep, 7,41928 (2017).

16. Hayashi, S., Ohtani, S., Good, T., Nojiri, Y., Saki, Y., Esumi, T. \& Kamiya, H. Identification of geosmin biosynthetic gene in geosmin-producing colonial cyanobacteria Coelosphaerium sp. and isolation of geosmin non-producing Coelosphaerium sp. from brackish Lake Shinji in Japan. Harmful Algae, 84,19-26 (2019).

17. Srinivasan, R. \& Sorial, G.A. Treatment of taste and odor causing compounds 2-methyl isoborneol and geosmin in drinking water: A critical review. J. Environ. Sci., 23, 1-13 (2011).

18. Hsieh, W.H., Chang, D.W. \& Lin, T.F. Occurrence and removal of earthy-musty odorants in two waterworks in Kinmen Island, Taiwan. J. Hazard. Toxic Radioact. Waste, 18, 04014012 (2014).

19. Japan Meteorological Agency Database. https://www.jma.go.jp (accessed on 1 January 2020) 
20. Kaplan, A and Reinhold, L. REINHOLD. $\mathrm{CO}_{2}$ concentrating mechanisms in photosynthetic microorganisms. Ann. Rev. Plant Physiol. Plant Mol. Biol., 50, 539-559 (1999).

21. Raven, J.A. Inorganic carbon acquisition by marine autotrophs. Adv. Bot. Res., 27, 87-209 (1997).

22. Tortell, P.D and Morel F. M. M. Sources of inorganic carbon for phytoplankton in the eastern Subtropical and Equatorial Pacific Ocean. Limnol. Oceanogr., 47, 1012-1022 (2002).

23. Morel, F. M. M. and Herring, J. G. Principles and applications of aquatic chemistry. Wiley (1993).

24. Cooper, T. D.; Filmer D.; Wishnick, M. and Lane, M. D. The active species of " $\mathrm{CO}_{2}$ " utilized by ribulose diphosphate carboxylase. J. Biol. Chem., 244, 1081-1083 (1969).

25. Shapiro, J. Blue-green algae: Why they become dominant. Science.,179, 382-384 (1973).

26. Burkhardt, S.; Riebsell, U. and Zondervan, I. Effect of $\mathrm{CO}_{2}$ concentration on C:N:P ratio in marine phytoplankton: A species comparison. Limnol. Oceanogr., 44, 683-690 (1999). 


\section{Figure legends}

Figure 1. Study area in Sanbe reservoir, Japan with field observation station, $\mu$ profiler.

Figure 2. Concentration of geosmin and 2-MIB at the epilimnion in Sanbe reservoir

Figure 3. Time-series change of geosmin at depths of $0.5 \mathrm{~m}$ below the surface of the water, $9 \mathrm{~m}, 17$ $\mathrm{m}$, and 27 (1 $\mathrm{m}$ above the bottom) $\mathrm{m}$ in Sanbe reservoir

Figure 4. Time-series change of 2-MIB at depths of $0.5 \mathrm{~m}$ below the surface of the water, $9 \mathrm{~m}, 17 \mathrm{~m}$, and $27 \mathrm{~m}$ (1 $\mathrm{m}$ above the bottom) in Sanbe reservoir

Figure 5. The vertical distribution of geosmin in 2016 when detected at a high concentration.

Figure 6. The vertical distribution of 2-MIB in 2017 when detected at a high concentration.

Figure 7. Comparison of the amount of inflow with Geosmin on the epilimnion from 2016 to 2018

Figure 8. Comparison of the amount of inflow with 2-MIB on the epilimnion from 2017 to 2019

Figure 9. The relationship between geosmin, 2-MIB, and water temperature on the epilimnion in Sanbe Reservoir from October 2015 to December 2019

Figure 10. The time-series changes at a depth of $1 \mathrm{~m}$ ( $\mu$ profiler data) at the Sanbe reservoir station and the inflow water temperature, rainfall from May to October 2017, 2018, and 2019. 


\section{Tables}

Table 1. The relative abundance of cyanobacteria at hypolimnion in Sanbe reservoir

\begin{tabular}{|c|c|c|c|c|}
\hline Sampling date & 2017.6 .22 & 2017.9 .1 & 2019.6 .27 & 2019.9 .25 \\
\hline Sampling depth & $0.5 \mathrm{~m}$ & $0.5 \mathrm{~m}$ & $1 \mathrm{~m}$ & $1 \mathrm{~m}$ \\
\hline Odor in the field & geosmin & 2-MIB & geosmin & 2-MIB \\
\hline Aphanocapsa sp. & - & $\mathrm{rr}$ & - & $r$ \\
\hline Aphanothece sp. & - & $r$ & - & - \\
\hline Microcystis novacekii & - & - & - & $\mathrm{rr}$ \\
\hline Microcystis sp. & - & - & r & $r$ \\
\hline Woronichinia naegeliana & - & - & $\mathrm{rr}$ & - \\
\hline Pseudanabena sp. ${ }^{* 1}$ & - & $r$ & - & + \\
\hline cf. Geitlerinema sp. ${ }^{* 3}$ & - & c & - & c \\
\hline cf. Cuspidothrix sp. ${ }^{* 3}$ & + & - & $\mathrm{rr}$ & - \\
\hline Aphanizomenon cf. flos-aquae ${ }^{* 1}$ & - & - & - & c \\
\hline Dolichospermum crassum ${ }^{* 2}$ & $r$ & - & + & - \\
\hline Dolichospermum planctonicum ${ }^{* 2}$ & - & - & $\mathrm{c}$ & - \\
\hline
\end{tabular}

c: abundant, + : common, r: rare, rr:very rare, - : absent.

*1: 2-MIB-producer, *2: geosmin-producer, *3: non-producer

Table 2. The monthly average of freshwater inflows for each year from 2016 to 2019 in Sanbe reservoir. Under line shows that it indicates month greater than 4-year average.

Inflow $\left(\mathrm{m}^{3} / \mathrm{s}\right)$

\begin{tabular}{|l|ccccccccccccc|c|}
\hline & Jan & Feb & Mar & Apr & May & Jun & Jul & Aug & Sep & Oct & Nov & Dec & Ave. \\
\hline 2016 & $\underline{\mathbf{1 . 7 5}}$ & $\underline{\mathbf{2 . 4 5}}$ & 1.36 & 1.38 & 1.08 & 0.92 & 1.47 & $\underline{\mathbf{1 . 0 0}}$ & $\underline{\mathbf{2 . 1 4}}$ & $\underline{\mathbf{1 . 8 2}}$ & $\underline{\mathbf{1 . 2 2}}$ & $\underline{\mathbf{2 . 0 4}}$ & $\underline{\mathbf{1 . 5 5}}$ \\
2017 & $\underline{\mathbf{1 . 9 1}}$ & $\underline{\mathbf{2 . 9 8}}$ & 1.60 & $\underline{\mathbf{1 . 6 8}}$ & 1.01 & 0.91 & 1.12 & $\underline{\mathbf{1 . 0 6}}$ & 1.91 & $\underline{\mathbf{1 . 9 6}}$ & $\underline{\mathbf{1 . 3 9}}$ & 1.22 & $\underline{\mathbf{1 . 5 6}}$ \\
2018 & 1.32 & 1.34 & $\underline{\mathbf{2 . 5 4}}$ & 1.39 & $\underline{\mathbf{1 . 9 0}}$ & $\underline{\mathbf{1 . 4 9}}$ & $\underline{\mathbf{2 . 3 3}}$ & 0.75 & $\underline{\mathbf{2 . 6 7}}$ & 1.62 & 0.94 & 1.33 & $\underline{\mathbf{1 . 6 4}}$ \\
2019 & 1.35 & 1.54 & 1.71 & $\underline{\mathbf{1 . 5 3}}$ & 0.80 & 0.83 & 1.00 & $\underline{\mathbf{0 . 9 5}}$ & 0.90 & 1.19 & 0.72 & 0.88 & 1.12 \\
\hline Ave. & 1.58 & 2.08 & 1.80 & 1.50 & 1.20 & 1.04 & 1.48 & 0.94 & 1.91 & 1.65 & 1.07 & 1.37 & 1.47 \\
\hline
\end{tabular}

Underlines indicate month greater than 4-year average. 


\section{Competing interests}

the authors declare no competing interests

\section{Acknowledgements}

This work was supported by the commissioned research from Shimane prefecture (2017-2019). The authors would like to thank the prefectural land maintenance office in Shimane prefecture for providing information about odorous compounds in Sanbe Reservoir. We would like to thank Editage (www.editage.com) for English language editing.

\section{Author contributions}

Conceptualization by Y.S and S.K, the field survey was S.M, S.H, K.A, and S.K, Analysis Geosmin and 2-MIB by S.H and S.M, identification of phytoplankton by S.O, data analysis, writing and visualization by S.K. All authors have read and agreed to the published version of the manuscript. 

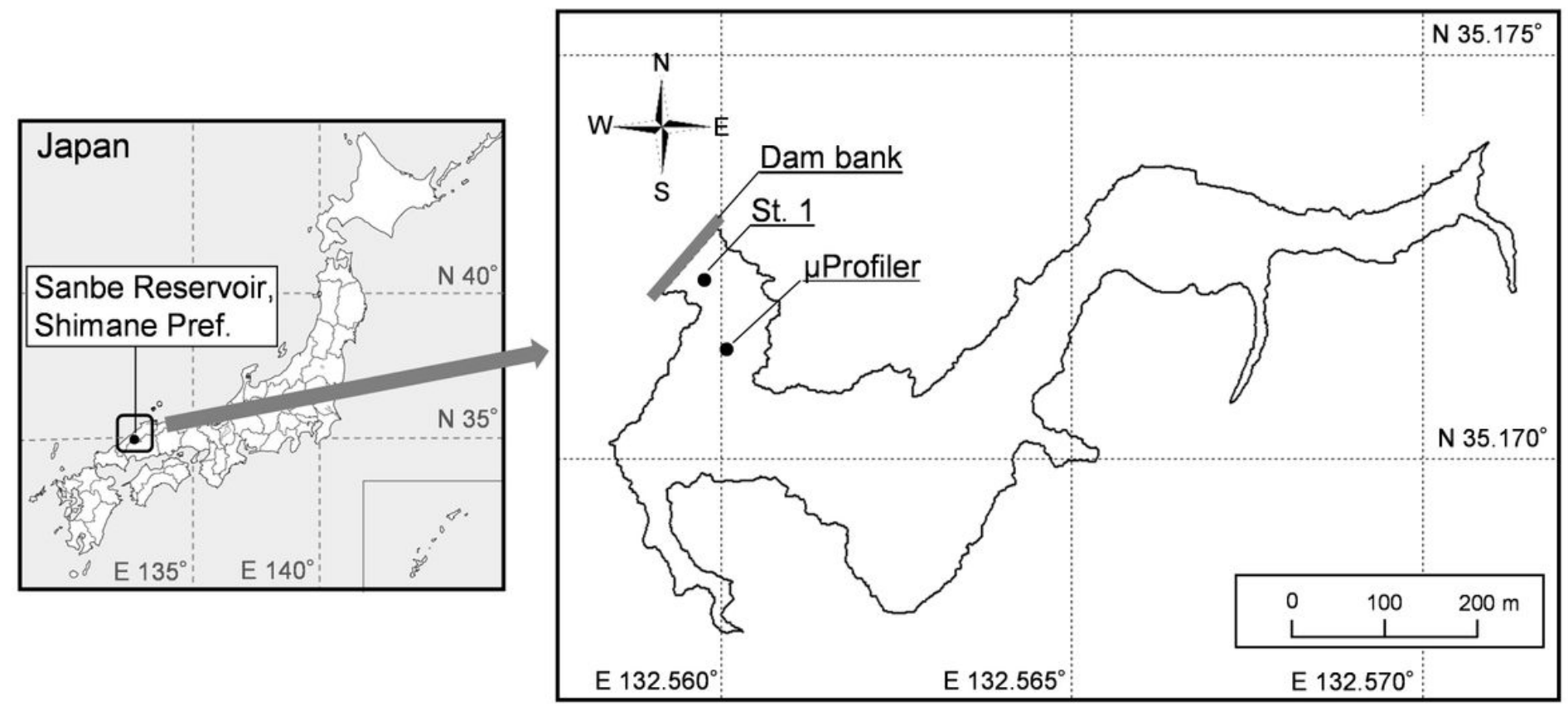

\section{Figure 1}

Study area in Sanbe reservoir, Japan with field observation station, $\mu$ profiler. Note: The designations employed and the presentation of the material on this map do not imply the expression of any opinion whatsoever on the part of Research Square concerning the legal status of any country, territory, city or area or of its authorities, or concerning the delimitation of its frontiers or boundaries. This map has been provided by the authors.

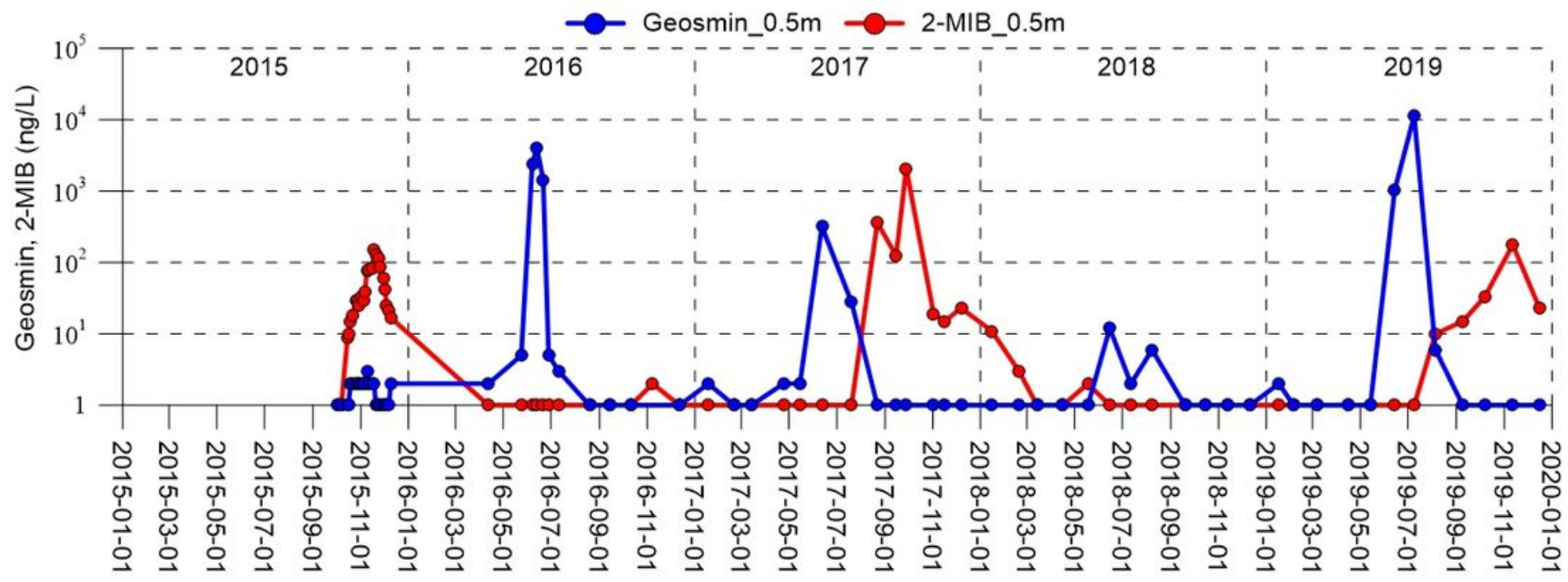

Figure 2

Concentration of geosmin and 2-MIB at the epilimnion in Sanbe reservoir 


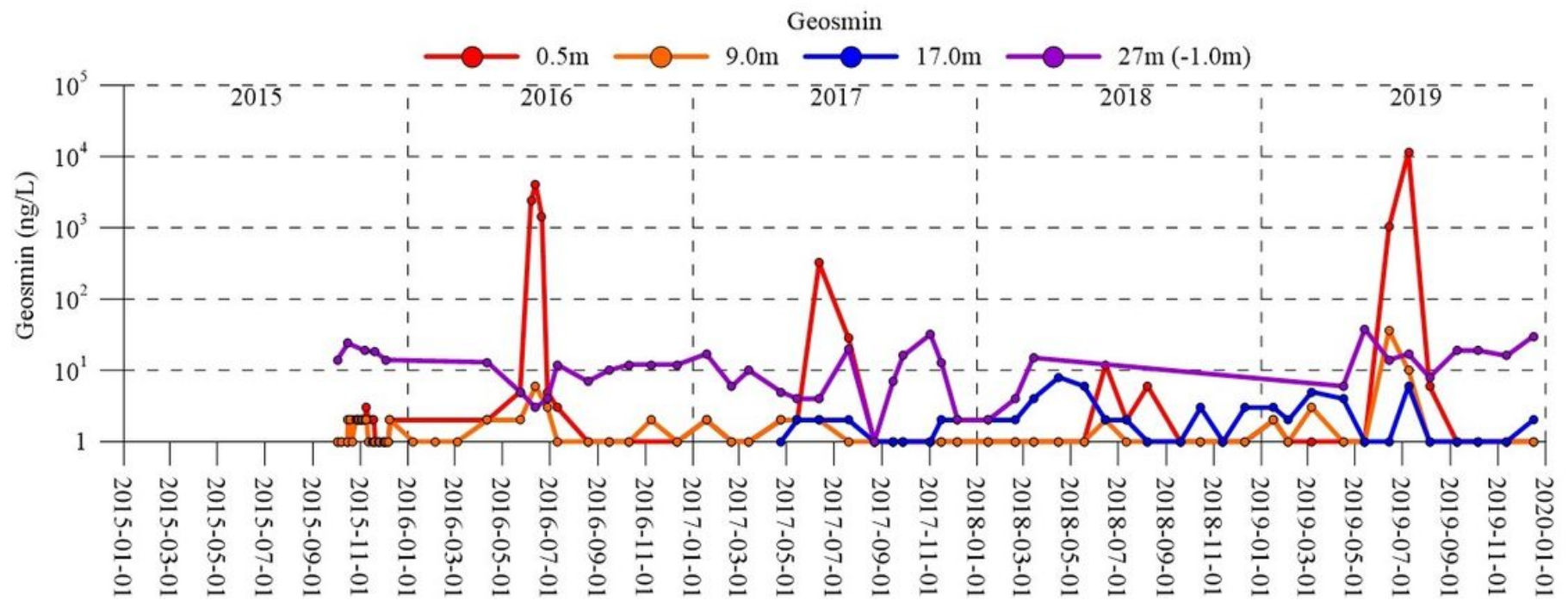

Figure 3

Time-series change of geosmin at depths of $0.5 \mathrm{~m}$ below the surface of the water, $9 \mathrm{~m}, 17 \mathrm{~m}$, and $27(1 \mathrm{~m}$ above the bottom) $\mathrm{m}$ in Sanbe reservoir

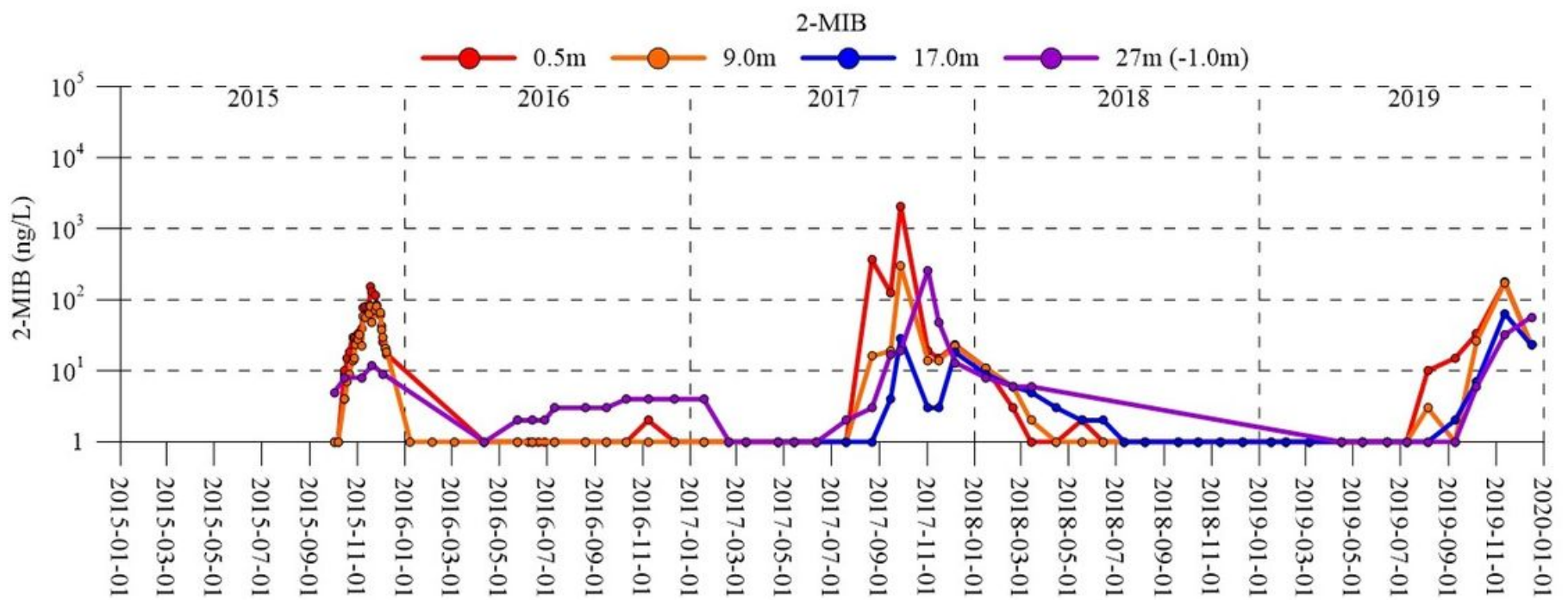

Figure 4

Time-series change of 2-MIB at depths of $0.5 \mathrm{~m}$ below the surface of the water, $9 \mathrm{~m}, 17 \mathrm{~m}$, and $27 \mathrm{~m}(1 \mathrm{~m}$ above the bottom) in Sanbe reservoir 


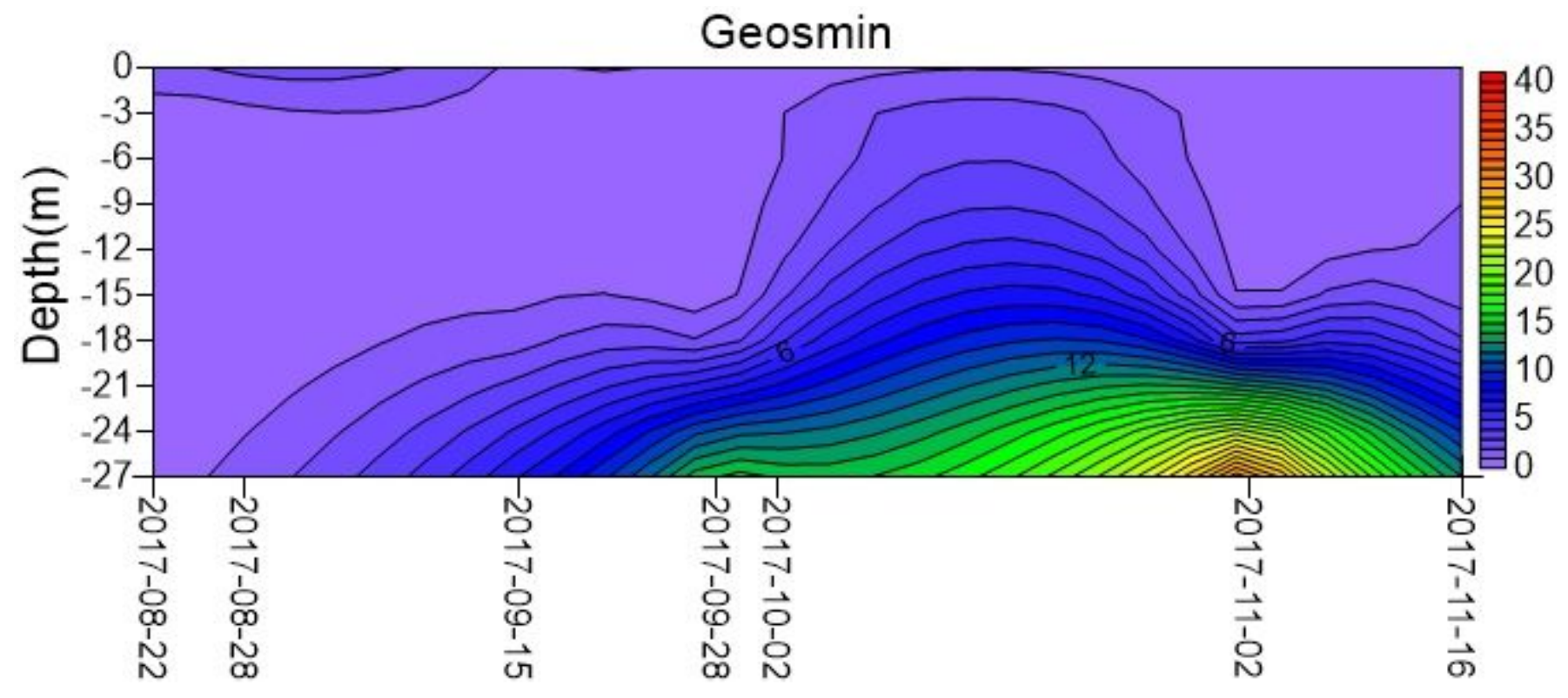

Figure 5

The vertical distribution of geosmin in 2016 when detected at a high concentration.

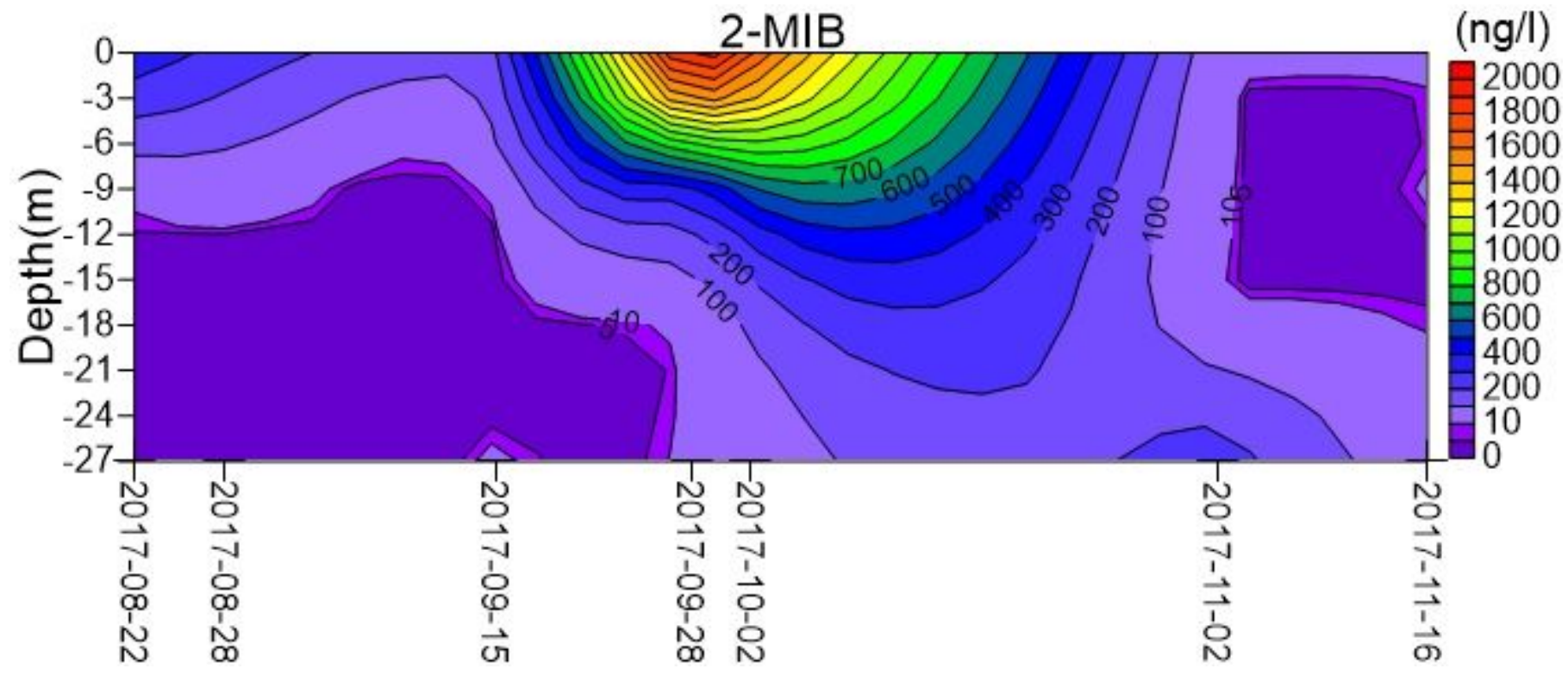

Figure 6

The vertical distribution of 2-MIB in 2017 when detected at a high concentration. 


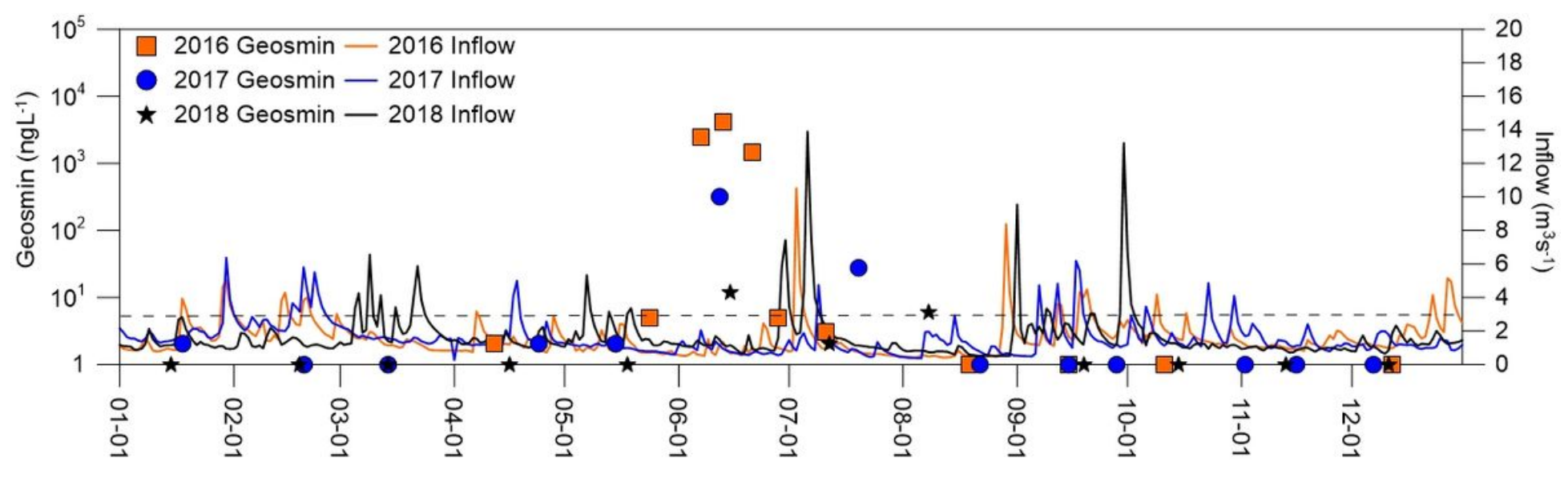

Figure 7

Comparison of the amount of inflow with Geosmin on the epilimnion from 2016 to 2018

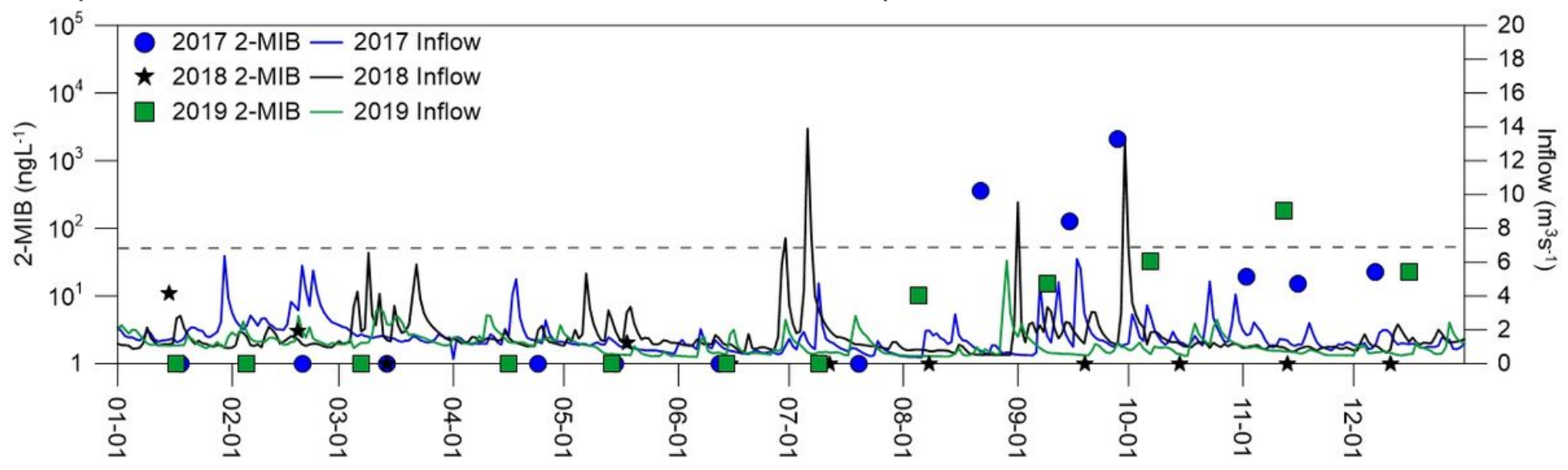

Figure 8

Comparison of the amount of inflow with 2-MIB on the epilimnion from 2017 to 2019 


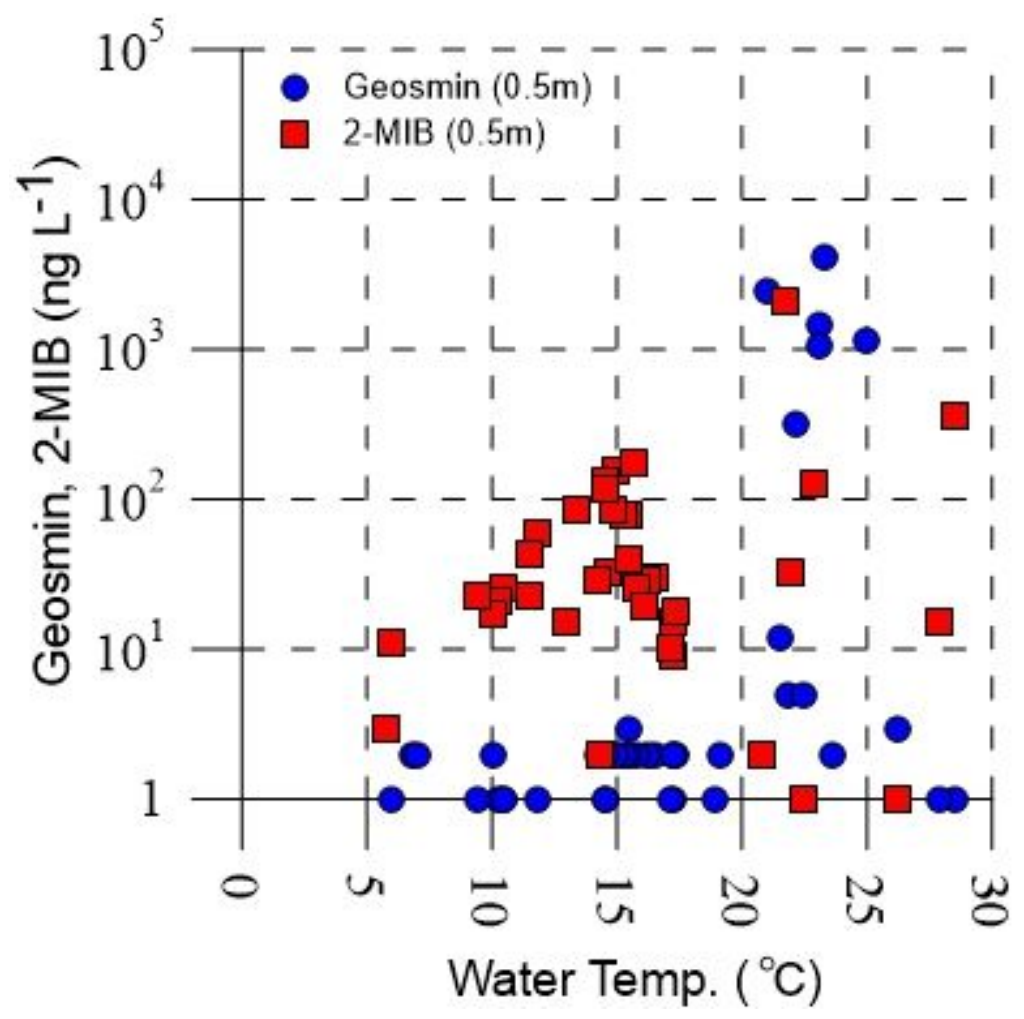

Figure 9

The relationship between geosmin, 2-MIB, and water temperature on the epilimnion in Sanbe Reservoir from October 2015 to December 2019

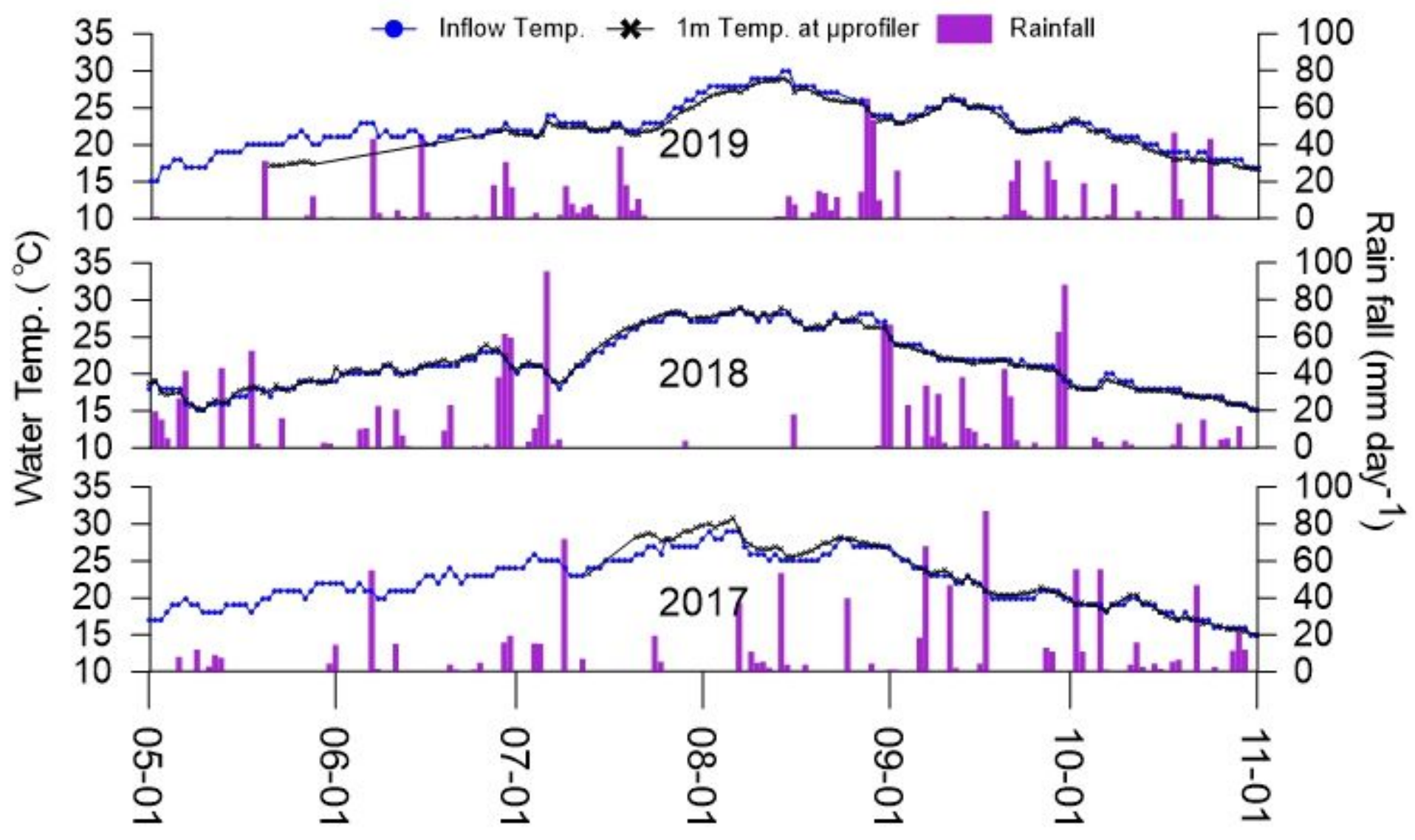


Figure 10

The time-series changes at a depth of $1 \mathrm{~m}$ ( $\mu$ profiler data) at the Sanbe reservoir station and the inflow water temperature, rainfall from May to October 2017, 2018, and 2019. 